\title{
The Miserable Loss from Yemeni Conflict: Can International Law Provide Reparation for Mental Injury?
}

\author{
Komang Ayu Nuriasih', I Made Budi Arsika² \\ ${ }^{1}$ Faculty of Law, Udayana University, Indonesia. E-mail: ayunuriasih007@gmail.com \\ 2 Faculty of Law, Udayana University, Indonesia.E-mail: budi_arsika@unud.ac.id
}

\begin{tabular}{l} 
ARTICLE INFO \\
\hline Keywords: \\
Armed Conflict; Yemen; \\
Mental Injuries; Reparation; \\
International Law \\
How to cite: \\
Nuriasih, K.A., and Arsika, \\
I.M.B. (2020). The Miserable \\
Loss from Yemeni Conflict: \\
Can International Law \\
Provide Reparation for \\
Mental Injury? Hasanuddin \\
Law Review, 6 (1): 66-79 \\
DOI: \\
10.20956/halrev.v6i1.2179 \\
\hline
\end{tabular}

\section{Introduction}

Aside from the biological factors and family history, what we experience in life -such as trauma or abuse, is one of many factors that contribute to our mental health problems. ${ }^{1}$ Scientific research suggests that the exposure to childhood trauma may lead to subsequent psychotic experiences, among others, the schizophrenia. ${ }^{2}$ Just as risky as it may sound, it is doubtless that huge stressors like witnessing a war or a conflict could victimize our mental well-being in a rapid span. What is miserable, however, is the fact that nearly all countries of the world are still involved in a conflict of some type that has resulted in casualties.

1 MentalHealth.gov. What Is Mental Health?. Available from <https://www.mentalhealth.gov/basics/what-ismental-health>. [Accesed 30 August 2019].

2 Grant Sara \& Julia Lappin (2017). Childhood Trauma: Psychiatry's Greatest Public Health Challenge?. The Lancet Public Health Journal, 2(7): 300, doi: https://doi.org/10.1016/S2468-2667(17)30104-4 
There were at least 49 armed conflicts that occurred in 2016, on 28 states and territories. ${ }^{3}$ The UN News also published that the year was marked an all-time high number of conflicts with 53 ongoings in 37 countries. ${ }^{4}$ This means that an estimated 888 million people out of 7.4 billion ${ }^{5}$ were scattered in many conflict zones, experiencing not only physical but also mental impacts. In addition, it is reported that more than one-in-five people who live in conflict-affected areas suffer from various types of mental illness. ${ }^{6}$

Yemen can be regarded as the home of the world's worst humanitarian crisis in 2019, as it placed the first list among 10 highlighted conflicts. ${ }^{7}$ The country was also ranked as number 160 among the 163 countries listed in Global Peace Index 20198, making it the fourth-worst. Yemen, therefore, can be an example of the horrifying threat of mental issues in a conflicting area.

The ongoing internationalized armed conflict in Yemen between Houthis (who belong to a small branch of Shia Muslims known as Zaydis ${ }^{9}$ ) and the Government of Yemen, is the one that would most likely generate perverse consequences to the civilians' mental well-being. The 2011 Arab Spring stimulated the conflict, when the wave of protests pushed President Ali Abdullah Saleh to transfer the authority to his deputy, Abdrabbuh Mansour Hadi. ${ }^{10}$ Unfortunately, President Hadi as the successor was overwhelmed by various problems during the transition, which later in 2014, Houthi took advantage of this situation and managed to control northern Saada (as well as the neighboring areas) -which marked the beginning of the fight.11 The fight then escalated when a Saudi Arabia-led military coalition intervened at the request of Yemen's new president in March 2015, 12 and has taken its toll on the Yemenis ever since.

Just as in other armed conflicts, there are allegations from various organizations against the misconduct of combatants that constitute violations of humanitarian laws. Human Rights Watch has been endeavored in documenting major violations of the conflicting parties. Taking small examples, from 90 unlawful coalition airstrikes to Houthi's indiscriminate artillery attacks and illegal weapons, it is emphasized that both Houthis and the Coalition have conducted attacks that may amount to war crimes. ${ }^{13}$ As assessed, both parties have violated the distinction and proportionality principles in

Rulac (Geneva Academy). The War Report: Armed Conflicts in 2016. Available from <http://www.rulac.org/news/thewar-report-armed-conflicts-in-2016>. [Accesed 30 August 2019].

4 UN News. One-in-five suffers mental health condition in conflict zones, new UN figures reveal. Available from <https://news.un.org/en/story/2019/06/1040281>. [Accesed 25 August 2019].

5 Population Reference Bureau. 2016 World Population Data Sheet. Available from <https://www.prb.org/wpcontent/uploads/2016/08/prb-wpds2016-web-2016.pdf>. [Accesed 25 August 2019].

6 Cristiane S. Duarte \& M. Claire Greene (2019). Guiding Policy and Practice to Address Mental Disorders in Conflict Settings. The Lancet Public Health Journal, 394 (10194): 192-194. doi: https://doi.org/10.1016/S0140-6736(19)31141-9

Robert Malley. 10 Conflicts to Watch in 2019. Available from <https://www.crisisgroup.org/global/10-conflictswatch-2019>. [Accesed 25 August 2019].

8 Institute for Economics \& Peace. Global Peace Index 2019. Available from <http://visionofhumanity.org/app/uploads/ 2019/07/GPI-2019web.pdf>. [Accesed 31 August 2019].

9 Patrick Wintour. Yemen civil war: the conflict explained. Available from <https://www.theguardian.com/world/ 2019/jun/20/yemen-civil-war-the-conflict-explained>. [Accesed 29 August 2019].

10 James Kearney. An examination of Saudi Arabia's airstrike rules of engagement and its protection of civilians. Available from <https://aoav.org.uk/2019/saudi-arabian-airstrikes-over-yemen-examined/>. [Accesed 29 August 2019].

11 BBC News. Yemen conflict explained in 400 words. Available from <https://www.bbc.com/news/world-middle-east44466574>. [Accesed 29 August 2019].

12 UN News. All sides in Yemen conflict could be guilty of war crimes, UN experts find. Available from <https:// news.un.org/en/story/2018/08/1017892>. [Accesed 1 September 2019].

13 Human Rights Watch. Yemen: Events of 2018. Available from <https://www.hrw.org/world-report/2019/countrychapters/yemen>. [Accesed 31 August 2019]. 
International Humanitarian Law (hereinafter, IHL), that may amount to war crimes. ${ }^{14}$ The conflicting parties also demonstrated the ignorance of IHL and International Human Rights Law while hampering the proper humanitarian assistance. 15

As a result of this complex catastrophe, various data reports have appeared. The Office of the United Nations High Commissioner for Human Rights (hereinafter, OHCHR) has documented that civilian casualties in Yemen from March 2015 to November 2018 reached a total of 17,640 persons. It comprises of 6,872 dead and 10,768 injured, where most of them were caused by Saudi Arabia-led coalition's airstrikes. ${ }^{16}$ Rulac has documented that more than 6,800 and 35,000 people were killed and injured from March 2015 to August 2016.17 Moreover, the "2018 Humanitarian Response Plan" stated that there were 9,245 conflicts related to deaths and more than 52,807 conflicts related to injuries as of late December 2017.18

Despite the conflict has resulted in physical losses, the civilians' mental well-being were sacrificed as the inevitable consequences. This is undeniably in line with the report by the World Health Organization's Secretariat, underlining that exposure to a humanitarian crisis can risk one's mental health conditions. ${ }^{19}$ Even worse, Yemenis have already gone through poor mental health problems before the civil unrest in 2011.20

In 2018, the New Arab wrote that according to studies, over five million people in Yemen affected psychologically by the war, in which serious psychological symptoms (bedwetting stuttering, psychological disorders, difficulty in concentration, and panic) were obviously indicated on the children. Accordingly, children in some regions (Sanaa, Aden, Taiz, and Abyan) specified a very considerable height of mental issues, such as fear, insecurity, anxiety, and anger. Moreover, 31\% of the children suffered physical symptoms which scientifically may be classified as psychological distress (e.g. headache, chest pain, abdominal pain and exhaustion). In this regard, psychologist Samira Qasem was in an opinion that such catastrophic have affected their behavior, leaving long-term psychological impacts and making them develop behavioral disorders. ${ }^{21}$

The "2019 Yemen Humanitarian Needs Overview" also indicated that child protection incidents reported in 2018 were at least 35\% related to mental health and psychosocial issues, on which in April 2018, 96\% of respondents noted 'significant changes' in the

14 UN News. All sides in Yemen conflict could be guilty of war crimes, UN experts find. Available from <https://news.un.org/en/story/2018/08/1017892>. [Accesed 1 September 2019].

15 United Nations Office for Coordination of Humanitarian Affairs (UN OCHA). 2018 Humanitarian Needs Overview: Yemen. Available from <https://reliefweb.int/sites/reliefweb.int/files/resources/yemen_humanitarian_needs_overview_ hno_2018_20171204_0.pdf>. [Accesed 1September 2019].

16 United Nations Human Rights: Office of the High Commissioner. Bachelet urges States with the power and influence to end starvation, killing of civilians in Yemen. Available from <https://www.ohchr.org/EN/NewsEvents/Pages/DisplayNews. aspx?NewsID=23855ELangID=E>. [Accesed 30 August 2019].

17 Rulac (Geneva Academy). The War Report: Armed Conflicts in 2016. Available from <http://www.rulac.org/news/thewar-report-armed-conflicts-in-2016>. [Accesed 30 August 2019].

18 UN OCHA. 2018 Humanitarian Response Plan: Yemen. Available from <https://reliefweb.int/sites/reliefweb.int/ files/resources/20180120_HRP_YEMEN_Final.pdf>. [Accesed 1 September 2019].

19 Report by Secretariat of World Health Organization (WHO) of 1 December 2011. Available from <http://apps.who.int/gb/ebwha/pdf_files/EB130/B130_9-en.pdf>. [Accesed 1 September 2019].

20 Sana'a Center for Strategic Studies (Sana'a Center). Yemen's Obligations to Respect, Protect, and Fulfil the Right to Mental Health: Submission to the UN Universal Periodic Review for Yemen. Available from $<$ http://sanaacenter.org/files/UPR_32nd_Session_2019_en.pdf>. [Accesed 1 September 2019].

21 A Yemeni Journalist. War takes heavy toll on Yemeni children's mental wellbeing. Available from <https://www.alaraby.co.uk/english/indepth/2018/8/20/war-takes-heavy-toll-on-yemeni-childrens-mental-wellbeing>. [Accesed 2 September 2019]. 
behavior, attitudes and psychosocial well-being of children and childcare providers. ${ }^{22}$ Moreover, a serious suggestion found in a Briefing Paper published by Sana'a Center (in collaboration with Columbia Law School and Mailman School of Public Health) stated that many people in Yemen seem suffered from detrimental psychosocial and emotional well-being consequences; with a hint derived from an interview between Tawfeek Al-Ganad and an official from the Yemen Ministry of Interior, saying that from 2014 to 2015, suicide rates in the capital rose some $40.5 \% .23$

As a part of studying team in Yemen, Fawziah Al-Ammar also found that mental health condition in Yemen is alarming, even if it's largely invisible outside the country. It is -indeed, alarming, knowing the fact that the Yemen's primary health care does not cover mental care and that no law currently exists in Yemen which addresses mental health. ${ }^{24}$ Although it is found that many of the Yemenis received government support, albeit modest and benefits from human resource development projects about in the past decade ${ }^{25}$, evaluations were still reaped at that time, thus not to question the current situation. The limited access to basic health services was faced by 19.7 million Yemenis while those non-communicable diseases killed more than what the projectiles and other weaponry attacks did to the peoples. ${ }^{26}$

Despite all huge and devastating impacts on Yemenis mental well-being, hope still arises and is worth keeping. As reported by UNICEF, there are 32,292 people in 16 governorates (including 27,537 children) who received psychosocial support in September 2019.27 Accordingly, a scientific research suggested a particular concern to the mental health that resulted from an armed conflict alongside the need to assess its effect on the countries' health system. ${ }^{28}$

Considering the importance of civilian's protection, it can be underlined that civilians in wartime need protection in two different situations. ${ }^{29}$ The first situation is civilian "as protected persons", where their rights can be violated by the 'enemy forces' who come into contact with them at usually outside the active war zones, and the second one is civilian "as targets during warfare", where they may not directly in hands or under control of the enemy, but become the collateral damage as the effect of active hostilities. Particularly -under the second situation, and noting all various data that reveal how Yemeni civilians are mentally affected by the war, it shall be underlined that not merely physical losses are necessary to be concerned. It is also unquestionable that the IHL upholds the fundamental principles of humanity, distinction,

22 UN OCHA. 2019 Humanitarian Needs Overview: Yemen. Available from <https://reliefweb.int/sites/reliefweb.int/files/ resources/2019_Yemen_HNO_FINAL.pdf>. [Accesed 2September 2019].

23 Sana'a Center, Columbia Law School Human Rights Clinic, Columbia University: Mailam School of Public Health. The Impact of War on Mental Health in Yemen: A Neglected Crisis. Available from <http://sanaacenter.org/files/ THE_IMPACT_OF_WAR_ON_MENTAL_HEALTH_IN_YEMEN.pdf>. [Accesed 1 September 2019].

24 Statement made by Fawziah Al-Ammar, on behalf of of the Sana'a Center for Strategic Studies, Columbia Law School Human Rights Clinic, and the Brown School at Washington University in St. Louis. Available from $<$ https://www.upr-info.org/sites/default/files/document/yemen/session_32_january_2019/2._sanaa_center_for_strategic_studies_presession_statement.pdf>. [Accesed 8 November 2019].

25 Maan A. Bari Qasem Saleh \& Ahmed Mohamed Makki. (2008). Mental Health in Yemen: Obstacles and Challenges. International Psychiatry, 5(4): 90. doi: https://doi.org/10.1192/S1749367600002277

26 Statement made by UN High Commissioner for Human Rights of 20 March 2019. Available from $<$ https://www.ohchr.org/EN/NewsEvents/Pages/DisplayNews.aspx?NewsID=24373ELangID=E>. [Accesed 1 September 2019].

27 UNICEF. Yemen Humanitarian Situation Report. Available from <https://www.unicef.org/appeals/files/UNICEF Yemen_Humanitarian_Situation_Report_Sept_2019.pdf>. [Accesed 9 November 2019].

28 Charbel El Bcheraoui, et al. (2018). Health in Yemen: Losing Ground in War Time. Globalization and Health, 14(1): 10. doi: https://doi.org/10.1186/s12992-018-0354-9

29 Robert Kolb \& Richard Hyde. (2008). An Introduction to the International Law of Armed Conflicts. Oxford: Hart Publishing, p. 221-222 
proportionality, and military necessity, where all these four principles were not heeded in the conflict at hand. Particularly, the conflict in Yemen showed how the distinction between civilians and combatants was being openly violated; resulting in a humanmade disaster that engraves long-lasting mental health consequences to the civilians.

It shall be acknowledged that there have been some studies that cover the issue of armed conflict in Yemen. Most legal writings merely focus on the legality of attacks and its physical impacts to the civilians and civil objects. The non-legal writings, especially on the issue of mental injury, tend to discuss the psychological situation of the victims, primarily children. The present article offers a general international law perspective in viewing the conflict, but in particular, proposing the possibility of applying international law in providing reparation access for the victims of mental injury caused by the conflict.

This article is aimed to discuss whether the mental impacts of an armed conflict are being acknowledged as one of the existing injuries, especially within legal instruments related to the IHL. Considering how important it is to seek the possible justification regarding the issue, this article broadens the view by involving the soft laws. Using both of the perspectives, this article will finally discuss and examine the availability of mental injury, or, in other terms -psychological damages, as one of the preconditions in demanding reparation before the International Criminal Court (hereinafter, ICC).

The outline of this writing can be described as follows. First of all, the introductory section describes the background, highlights the issues, and specifies the aim of this paper. It reveals the armed conflict situation in Yemen and its catastrophic impact, mainly, to the civilians. Next, it explains the method of this legal writing, in which the authors very much rely on available interned-based sources to collect information and use various types of legal documents, reports, and secondary sources as an academic tool of analysis. Subsequently, it turns into the main analysis and discussion that consists of two subsections that elaborate on each legal issue to come up with the intended output of the article. The first sub-section explores the relevant international and national legal instruments related to IHL, while the second sub-section focuses on the analysis of both hard law and soft law instruments in assessing the availability of mental injury in Yemeni armed conflict as the precondition for reparation before the International Criminal Court. Lastly, it concludes by summing up the findings and analysis.

\section{Method}

This article reflects a legal research that focuses on mental issues as the post-war impacts -especially from the perspective of IHL, rather than finger-pointing the responsible party for the conflict in Yemen that has not yet been resolved. The analysis very much relies on statutory, case, comparative, and conceptual approaches. It refers to various sources and materials, including both international and national legal instruments, international judgments, international resolutions, case laws, textbooks, journals, and website contents like reports, data-findings, and studies. 


\section{Mental Injury Viewed from Legal Instruments Related to International Humanitarian Law}

\subsection{International Instruments}

There has been no statutory definition of 'injury' in the perspective of IHL. The Black's Law Dictionary (hereinafter, Black's Law) defines it as "the violation of another's legal right, for which the law provides a remedy; a wrong or injustice" ${ }^{30}$. Not merely 'injury' is a single general term, it is also categorized forward into many terms with different indications, such as compensable injury, physical injury, serious bodily injury, et cetera. On the other hand, the use of various terminologies of 'injury' in IHL was not originated from such compact provisions as they seemingly do in Black's Law through each definitive category.

Most importantly, neither Black's Law nor instruments related to the IHL categorize a distinction between physical injury and mental injury. However, it is regulated -for example, in the classification of 'wounded and sick' in Additional Protocol I to the Geneva Convention 1949, that the term refers to persons (whether military or civilian), whom because of their mental disorder or disability may in need of medical assistance or care. ${ }^{31}$ Furthermore, international instruments related to the IHL which provide provisions with respect to mental health can be found below.

a. Rome Statute of the International Criminal Court (hereinafter, Rome Statute)

i. 'Genocide' according to Article 6, is the acts intended to destroy a national, ethnical, racial or religious group -either wholly or partly, such one of which can cause serious bodily or mental harm to the targeted members. ${ }^{32}$

ii. 'Crimes against humanity' according to Article 7, is a part of a widespread or systematic attack directed against the civilian population, where such two of them are 'torture' and 'other acts classified as inhumane acts', with a similar characteristic to other classification in the article, that may intentionally cause great suffering or serious injury to body or mental or physical health. ${ }^{33}$

iii. The act of 'torture' as elaborated forward in paragraph 2, is an intentional physical or mental infliction of severe pain or suffering, to a person in the custody or under the control of the accused. 34

b. Geneva Convention of 12 August 1949 (hereinafter, Geneva Convention IV)

i. Mental health-related provision is faintly mentioned in Geneva Convention IV, other than in Chapter IV regarding "Hygiene and Medical Attention", as Article 91 regulates concerning the isolation wards for contagious or mental diseases' cases. ${ }^{35}$

ii. However, related to the grave breach of the convention, it is regulated in Article 147 that "torture or inhuman treatment" 36 is one of the acts that constitute the grave breach. If we attribute these two acts to the previous instruments, it can be found that mental health is considered within each definition of both acts.

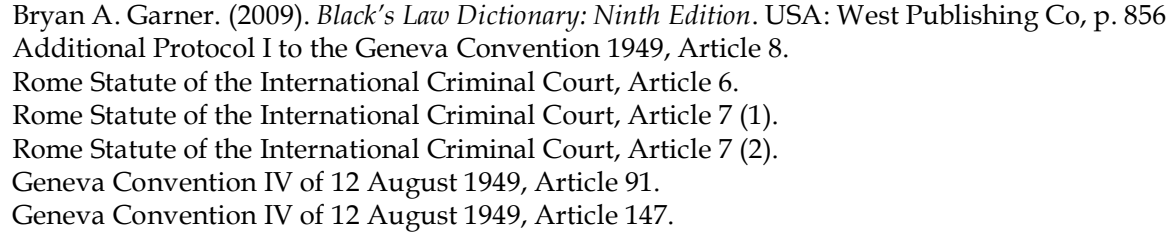


c. Additional Protocol I to the Geneva Conventions of 12 August 1949 (hereinafter, Additional Protocol I)

Mental health-related provisions can mostly be found within Additional Protocol I, as:

i. Article 8 defines the terminology of "wounded" and "sick", as who refrain from the hostility and require medical care because of trauma, disease or other physical or mental disorder or disability. ${ }^{37}$

ii. Relational to the next provision in Article 9, it is regulated that provisions with intent to ameliorate the condition of the wounded and sick as defined above, shall apply to them in a situation referred to in Article 1 of the Protocol, and without adverse distinction. ${ }^{38}$ Meaning that, subsequently, all other provisions related to the amelioration on the condition of those persons are intended to guarantee their rights.

iii. Still relational to the next provision in Article 10, it is regulated that all persons from whichever the Party, having the condition referring to the provisions above, shall be respected, protected and in all circumstances shall be treated humanely and receive fully practicable medical care with the least possible delay. They shall also receive the attention required by their condition without any distinction other than the medical ones. ${ }^{39}$ However, since there has been no elaboration regarding the distinction on the medical ground, it will be such rigors if the condition could somehow result in the imparity for the protection and treats addressed to the mental sufferer.

iv. Explicitly, it is stated in Article 11 that the physical or mental health and integrity of persons shall not be endangered by any unjustified act or omission, of which if violated may be considered as a grave breach. ${ }^{40}$

v. Further, Article 75 (Fundamental Guarantees) re-emphasizes the prohibition against "torture of all kinds" that may violate the life, health, or physical or mental well-being of persons, whether the torture is physical or mental. ${ }^{41}$

\section{d. Customary International Humanitarian Law (hereinafter, CIHL)}

i. In Rule 90 of CIHL, both torture and inhuman treatment are defined as "severe physical or mental pain or suffering". The only distinction between these treatments is that torture is committed for a specific purpose. ${ }^{42}$

ii. Moreover, it is stated in Rule 156 of CIHL that serious violations of IHL constitute war crimes. ${ }^{43}$

\subsection{National Instruments}

Retrieving the IHL's principles and concerns, provisions related to mental health in armed conflict can also be found within the national instruments in various countries. Briefly, they can be found in several examples as in both Yemen's Military Criminal Code $^{44}$ and France's Law of Armed Conflict Manual45, which regulate that attacks and

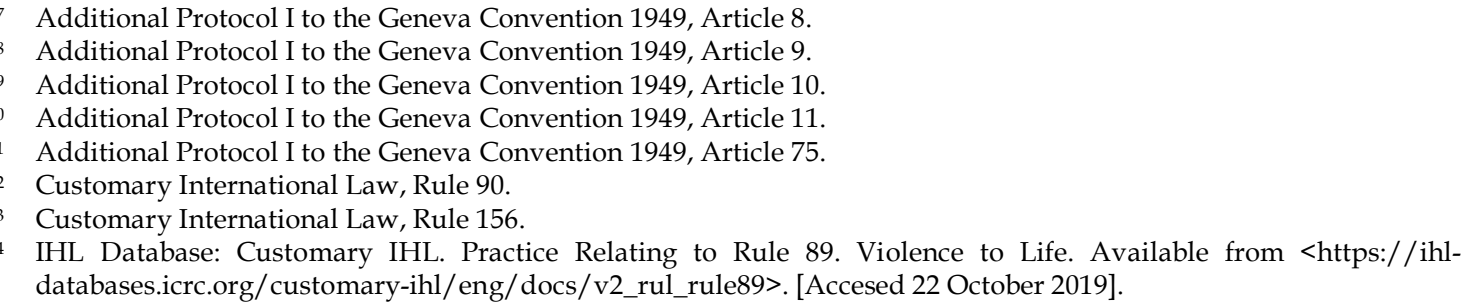


grave attempts to the physical and mental well-being of civilians constitute war crimes. Moreover, the Military Manual of the Netherlands46, Peru's International Humanitarian Law Manual ${ }^{47}$, the UK Law of Armed Conflict Manual ${ }^{48}$ and Australia's Law of Armed Conflict Manual ${ }^{49}$ regulate the prohibition against violence against the life, health or physical or mental well-being of persons, especially with respect to the civilian population.

From these international legal instruments related to the IHL, it can be found within the formulations that mental health has been concerned and thereby the protection of civilians is provided -as far as the existing regulations. However, we cannot find such 'mental injury' existed in the perspective of the law, to which we can examine how far it is being acknowledged. There have been no explicit provisions that classify mental injury or psychological damage into a specific categorization within many impacts resulted from war -for instance as "serious bodily injury" does exist in the perspective of CIHL, yet these mental consequences exist in real life as they happen within the ongoing conflicts in Yemen.

By comparing the national instruments with international instruments, it can be found that it is more clearly-emphasized within the national ones in prioritizing the protection of civilians' mental well-being. However, the perspectives of both instruments have not explicitly stipulate mental consequences as an inevitable consequence of any act conducted in the name of war. Meaning that, even such violation was not directly addressed to someone -or someone was not directly affected by the violation, one's mental condition is most likely sacrificed.

Further, taking into account that more than twenty percent of those who live in affected areas of conflict is the victim of mental illness, an urgency to give our eyes to the civilian's mental well-being, as well as to the Yemenis, is high. People are already suffering only by living in a conflict area and witnessing war, not to mention a conflict which consists of many violations that may amount to war crimes from the perspective of IHL, especially the principle of distinction as conducted by the parties in the ongoing conflict in Yemen. Hence, referring to all the discovered data, this conflict can be an essential reminder that mental consequences carry huge and the long-term adverse risks of a war, although the regulations have not been so hospitable.

Accordingly, without further acknowledgment within prevailing legal instruments, especially those related to the IHL, the stigma around mental impacts of a conflict or a war may persist and could obstruct the urgency to stand up for all the innocents who are living with these invisible scars, and thereby to focus on recovering their fragile conditions. 


\section{The Availability and Acknowledgment of Mental Injury in the Yemeni War as the Precondition for Reparation before the International Criminal Court}

The availability of mental injuries, or, in the other terms -psychological damages (that has been afflicting the Yemenis) as the precondition for reparation, can be analyzed through the existing legal instruments related to the IHL, as well as past international cases related to the issue. This analysis is intended to find out whether such loss of mental injuries can be acknowledged as one of the considerations in demanding reparation before the ICC, alongside the physical losses such as bodily injury and deaths as resulted in most cases.

\subsection{Hard Law's Perspective}

The term 'hard law' in general refers to state parties' binding legal obligations that can be enforced before a tribunal..$^{50}$ The availability and acknowledgment of mental injury or psychological damage as one of the considerations in demanding a reparation can firstly be analyzed by scrutinizing international hard law instruments with respect to the reparation, as elaborated below.

- Rome Statute of the ICC, where Article 75 (1) and (2) of the Statute regulates that the Court shall establish principles relating to reparations and may make a direct order against a convicted person with the appropriate reparations, to the victims or in respect of them. ${ }^{51}$

- Geneva Convention IV, using the terms of "Responsibilities of the Contracting Parties", stated in Article 148 that no High Contracting Party shall be allowed to absolve itself or any other High Contracting Party of the liability respecting the breaches committed by itself or another High Contracting Party. 52

- Additional Protocol I regulates specifically regarding the 'Compensation' in Article 91, that a party to the conflict may be liable to pay compensation -if the case demands, in respect to the violations to the Protocol. ${ }^{53}$

- CIHL, in Chapter 42, regulates the State's responsibility for violations of IHL and reparation, where Rule 149 elaborates the categorization of persons committing violations on behalf of the State, and Rule 150 emphasizes that a State is required to make full reparation for the loss or injury caused by violating the IHL. 54

Referring to the provisions in CIHL, it can be found that the responsibility for violations of IHL -and therefore to conduct a reparation, is measured through the subject who committed the violations itself on behalf of a Country. Meaning that, without the need to consider both physical and mental injuries or psychological damages caused by the acts, a State can hold the responsible then obliged to provide full reparation before the ICC. However, it is important to remember that these losses will be the judges' consideration in adopting decisions and measuring the form and amount of the reparation. It can also be stressed that the meaning of 'full reparation' remains debatable, but it can be assumed -for the sake of clarity, that 'full' means

50 See European Center for Constitutional and Human Rights. Term: Hard Law / Soft Law. Available from <https://www.ecchr.eu/en/glossary/hard-law-soft-law/>. [Accesed 22 October 2019].

51 Rome Statute of the International Criminal Court, Article 75 (1) \& (2).

52 Geneva Convention IV of 12 August 1949, Article 148.

53 Additional Protocol I to the Geneva Convention 1949, Article 91.

54 Customary International Humanitarian Law, Rule 149 \& 150. 
exactly what that word conveys to an ordinary person. ${ }^{55}$ The Geneva Convention IV and the Additional Protocol I emphasize that reparation adheres to a party for the violation conducted.

Most importantly, Rome Statute of the ICC recognizes that restitution, compensation and rehabilitation are types of reparation. The Court may also decide the range and coverance of any damage, loss and injury, which shows that the measurement and consideration to demand reparation may be varied and may not be merely focused on the physical ones.

\subsection{Soft Law's Perspective}

Soft law refers to non legally binding documents that establish a specific standard, usually in the form of guidelines, policy declarations, or codes of conduct, 56 that relatively lack of enforceability. ${ }^{57}$ A State may realize more value from their commitments by reducing the losses of undeterrable violations. ${ }^{58}$ In other words, soft law can be classified as a morally binding instrument.

Following such value to acknowledge mental injury or psychological damage as one of the preconditions in demanding reparation before the ICC, soft law (e.g. the Resolution of UN Security Council, Decision of the Court ${ }^{59}$ ) can contribute in giving more valuable sights, for instance, the analysis of mental harm can first be seen in Kajelijeli case.

The Trial Chamber II of International Criminal Tribunal for Rwanda (hereinafter, ICTR) ruled in Kajelijeli case 60 that in defining 'bodily' or 'mental' harm, a case-by-case based approach is required. Moreover, in defining a 'serious mental harm', the Trial Chamber in Kayishema and Ruzindana delimits the term as what includes more than "minor or temporary impairment of mental faculties; such as the infliction of strong fear or terror, intimidation or threat". The case-by-case approach in the judgment of Kajelijeli case is most likely the proper answer in determining mental harm, since the harm itself has never been clearly defined in the perspective of hard laws. If we refer forward to the Kayishema and Ruzindana as ruled in Kajelijeli above, the infliction of strong fear or terror as one of the parameters of serious mental harm can be attributed to the ongoing conflict in Yemen, and thereby may be qualified as so.

In addition, Resolution No. 2475 (2019) of the UN Security Council61 stated that persons with disabilities, including the psychosocial ones, shall be guaranteed their full enjoyment without any discrimination. However, it is unclear that the term 'disabilities' here is aimed for those who have been experiencing psychosocial issues as the impacts of a war or a conflict, or those who have been experiencing such issues long before the conflict occurred.

55 Andrea Gattini (2002). The UN Compensation Commission: Old Rules, New Procedures on War Reparations. European Journal of International Law, 13(1): 162. do: https://doi.org/10.1093/ejil/13.1.161

56 See Bryan A. Garner (2009). Black's Law Dictionary: Ninth Edition. USA: West Publishing Co, p. 1519

57 See Mauro Barelli (2009). The Role of Soft Law in the International Legal System: the Case of The United Nations Declaration on The Rights of Indigenous Peoples. International \& Comparative Law Quarterly, 58(4): 959. doi: https://doi.org/10.1017/S0020589309001559

58 Andrew T. Guzman \& Timothy L. Meyer (2010). International Soft Law. Journal of Legal Analysis, 2(1): 222. doi: https://doi.org/10.1093/jla/2.1.171

59 Statute of the International Court of Justice, Article 38 (1).

60 International Criminal Tribunal for Rwanda, Prosecutor v. Juvénal Kajelijeli, Judgment and Sentence of 1 December 2003, ICTR-98-44A-T, para. 815, reffering to Kayishema and Ruzindana, Judgement, TC, para. 110; Semanza Trial Judgement, para. 321 .

61 Resolution of the UN Security Council, No. 2475 (2019). 
In Lubanga case62, the Appeals Chamber of the ICC defined the harm to direct and indirect victims caused by crimes, including psychological trauma and the development of psychological disorders, such as suicidal tendencies, depression, dissociative behaviour, and psychological suffering. If we refer to this judgment, it can be known that mental injuries or psychological damages can be one of the applicable considerations before the ICC. It is also necessary that 'psychological trauma' as mentioned above is being attributed to the tendencies to develop psychological disorders, as well as the classification of both direct and indirect victims since the war caused not merely direct victims.

It is generally understood that States, as the main subject of international law, may not prioritize soft laws in resolving international cases and tensions. This, however, does not mean that international society ignores the existence and the development of soft laws as widely accepted instruments, especially in a moral sense. Recalling the provisions in the aforementioned soft laws, all these findings can doubtlessly be attributed to the ongoing conflict in Yemen -one that has been resulting in mental injuries and psychological damages to its civilians since 2014. Further, after the conflict is over and thereby a proper reparation is demanded to the individuals, mental injuries and psychological damages shall be acknowledged and be fairly considered as the preconditions and basis to demand such reparation, especially in a form of compensation.

\section{Conclusion}

The acknowledgment of mental injuries or psychological damages as the invisible-yetinevitable consequence of an armed conflict still needs to be taken into concern and consideration. It is mainly assessed from the existing instruments related to the IHL, that there has been no explicit provision within the instruments which categorizes such impacts into injuries like the physical ones. The availability of mental injury or psychological damage to be applied before the ICC has also remained blurry from the perspective of hard law.

However, referring to the soft law like the judgments from past cases may contribute to similar issues, where valuable sights can be easier to get and the existing stigmas can slowly be reduced. Since the approach of soft law can lead mental injury or psychological damage as one of the applicable considerations before the ICC, it can be attributed to the ongoing conflicts in Yemen that they shall also be applicable in demanding reparation -especially compensation, once the conflict is over. It is also important to adjust the form of compensation that will be given to the Yemenis, such as in the form of establishing mental health center that specializes and focuses on taking care of the mental sufferer, as well as to promote the mental health.

In the end, it is essential to give our eyes on data findings concerning the mental impacts of war. International society should acknowledge the fact that all mental consequences of war -not only in Yemen, are indeed real. It is therefore, legal researchers should conceive a legal concept that ensure the availability of reparation of mental injury, to be further adopted in relevant legally binding international instruments.

62 International Criminal Court, Prosecutor v. Thomas Lubanga Dyilo, Public Document Judgment Issued on 3 March 2015, ICC-01/04-01/06AA2A3, para. 191. 


\section{References}

Book

Robert Kolb \& Richard Hyde. (2008). An Introduction to the International Law of Armed Conflicts. Oxford: Hart Publishing.

Journal Article

Mauro Barelli. (2009). "The Role of Soft Law in the International Legal System: the Case of The United Nations Declaration on The Rights of Indigenous Peoples" International \& Comparative Law Quarterly, 58(4): 957-983.

Charbel El Bcheraoui, et al. (2018). "Health in Yemen: Losing Ground in War Time" Globalization and Health, 14(1): 10.

Cristiane S. Duarte \& M. Claire Greene. (2019). “Guiding Policy and Practice to Address Mental Disorders in Conflict Settings" The Lancet Public Health Journal. 394(10194): 192-194.

Andrea Gattini. (2002). "The UN Compensation Commission: Old Rules, New Procedures on War Reparations" European Journal of International Law. 13(1): 161181.

Andrew T. Guzman \& Timothy L. Meyer. (2010). "International Soft Law" Journal of Legal Analysis, 2(1): 171-225.

Maan A. Bari Qasem Saleh \& Ahmed Mohamed Makki. (2008). "Mental Health in Yemen: Obstacles and Challenges" International Psychiatry, 5(4): 90-92.

Grant Sara \& Julia Lappin. (2017). "Childhood Trauma: Psychiatry's Greatest Public Health Challenge?" The Lancet Public Health Journal, 2(7): 300-301.

\section{Dictionary}

Bryan A. Garner. (2009). Black's Law Dictionary: Ninth Edition. USA: West Publishing Co.

\section{World Wide Web}

A Yemeni Journalist. (2018). War takes heavy toll on Yemeni children's mental wellbeing. Available online from: https://www.alaraby.co.uk/english/indepth/2018/8/20/wartakes-heavy-toll-on-yemeni-childrens-mental-wellbeing. [Accesed September 2, 2019].

BBC News. (2018). Yemen conflict explained in 400 words. Available online from: https://www.bbc.com/news/world-middle-east-44466574. [Accesed August 29, 2019].

European Center for Constitutional and Human Rights. Term: Hard Law / Soft Law. Available online from: https://www.ecchr.eu/en/glossary/hard-law-soft-law/. [Accesed October 22, 2019].

IHL Database: Customary IHL. Practice Relating to Rule 89. Violence to Life. Available online from: https://ihl-databases.icrc.org/customary-ihl/eng/docs/v2_rul_rule89. [Accesed October 22, 2019].

James Kearney. (2019). Saudi Arabia's airstrike rules of engagement reviewed. Available online from: https://aoav.org.uk/2019/saudi-arabian-airstrikes-over-yemen-examined/. [Accesed August 29, 2019]. 
Robert Malley. (2019). 10 Conflicts to Watch in 2019. Available online from: https://www.crisisgroup.org/global/10-conflicts-watch-2019. [Accesed August 25, 2019].

MentalHealth.gov. (2019). What Is Mental Health?. Available online from https://www.mentalhealth.gov/basics/what-is-mental-health. [Accesed August 30, 2019].

United Nations Human Rights: Office of the High Commissioner. (2018). Bachelet urges States with the power and influence to end starvation, killing of civilians in Yemen. Available online from: https://www.ohchr.org/EN/NewsEvents/Pages/ DisplayNewRs.aspx?NewsID=23855ELangID=E. [Accesed August 30, 2019].

UN News. (2018). All sides in Yemen conflict could be guilty of war crimes, UN experts find. Available online from: https://news.un.org/en/story/2018/08/1017892. [Accesed September 1, 2019].

UN News. (2019). One-in-five suffers mental health condition in conflict zones, new UN figures reveal. Available online from: https://news.un.org/en/story/2019/06/1040281. [Accesed August 25, 2019].

Patrick Wintour. (2019). Yemen civil war: the conflict explained. Available online from: https://www.theguardian.com/world/2019/jun/20/yemen-civil-war-theconflict-explained. [Accesed August 29, 2019].

Sana'a Center, Columbia Law School Human Rights Clinic, Columbia University: Mailam School of Public Health. (2017). The Impact of War on Mental Health in Yemen: A Neglected Crisis. Available online from: http://sanaacenter.org/files/THE_IMPACT_OF_WAR_ON_MENTAL_HEALTH_IN_ YEMEN.pdf. [Accesed September 1, 2019].

Sana'a Center for Strategic Studies (Sana'a Center). (2019). Yemen's Obligations to

Respect, Protect, and Fulfil the Right to Mental Health: Submission to the UN Universal Periodic Review for Yemen. Available online from: $h$ ttp://sanaacenter.org/files/UPR_ 32nd_Session_2019_en.pdf. [Accesed September 1, 2019].

Legal Documents

Additional Protocol I to the Geneva Conventions of 12 August 1949, relating to the Protection of Victims of International Armed Conflicts

Australia's Law of Armed Conflict Manual (2006)

Customary International Humanitarian Law (CIHL)

France's Law of Armed Conflict Manual (2001)

Geneva Convention IV of 12 August 1949, Relative to the Protection of Civilian Persons in Time of War

Peru's International Humanitarian Law Manual (2004)

Rome Statute of the International Criminal Court

Statute of the International Court of Justice

The Military Manual of the Netherlands (2005)

The United Kingdom Law of Armed Conflict Manual (2004)

United Nations Security Council Resolution No. S/RES/2475 (2019) of 20 June 2019

Yemen's Military Criminal Code (1998) 
Case Law

International Criminal Court, Prosecutor v. Thomas Lubanga Dyilo, Public Document Judgment Issued on 3 March 2015, ICC-01/04-01/06AA2A3.

International Criminal Tribunal for Rwanda, Prosecutor v. Juvénal Kajelijeli, Judgment and Sentence of 1 December 2003, ICTR-98-44A-T.

Other Documents

Human Rights Watch. Yemen: Events of 2018, 2018.

Institute for Economics \& Peace. Global Peace Index 2019, 2019.

Population Reference Bureau. 2016 World Population Data Sheet, 2016.

Report by Secretariat of World Health Organization (WHO), December 2011.

Rulac (Geneva Academy). The War Report: Armed Conflicts in 2016, 2016.

Statement by Dr. Fawziah Al-Ammar, on behalf of of the Sana'a Center for Strategic Studies, Columbia Law School Human Rights Clinic, and the Brown School at Washington University in St. Louis.

Statement by United Nations High Commissioner for Human Rights, March 2019.

United Nations Office for the Coordination of Humanitarian Affairs. 2018 Humanitarian Needs Overview: Yemen, 2018.

United Nations Office for the Coordination of Humanitarian Affairs. 2019 Humanitarian Needs Overview: Yemen, 2019.

United Nations Office for the Coordination of Humanitarian Affairs. 2018 Humanitarian Response Plan: Yemen, 2018.

United Nations Office for the Coordination of Humanitarian Affairs. Yemen Humanitarian Situation Report, September 2019.

\section{Conflict of Interest Statement:}

The author(s) declares that the research was conducted in the absence of any commercial or financial relationships that could 